\title{
Перший досвід застосування синтетичного антитромбіну-ІІІ (Атенатив) у кардіохірургічній практиці
}

\author{
Дьогтяр В. В., Бойченко О. М., Жовнір В. А., Чанглі Н. О. \\ ДУ «Науково-практичний медичний центр дитячої кардіології та кардіохірургії МОЗ України» (Київ)
}

\begin{abstract}
В наші дні основна кількість операцій на серці проводиться в умовах штучного кровообігу, що супроводжується порушенням гемостазу. Дефіцит антитромбіну-III становить $0,02-1 \%$ серед населення. Головним клінічним проявом недостатності антитромбіну-ІІІ $є$ тромбози. В роботі проведено власне дослідження зв'язку між рівнем антитромбіну-ІІІ та результатом активованого часу згортання під час штучного кровообігу в кардіохірургічній практиці. Продемонстровано, що кількісна i/або якісна недостатність антитромбіну-ІІІ призводить до ранніх післяопераційних ускладнень і порушень у системі гемостазу.

Протягом 2016 року на базі ДУ «Науково-практичний медичний центр дитячої кардіології та кардіохірургії» був проведений аналіз рівня антитромбіну-III у 11 пацієнтів, середній вік яких складав 50,2 27,2 року. У 5 (45,4\%) пацієнтів було наявне супутнє захворювання: у $4(36,4 \%)$ пацієнтів - інфекційний ендокардит, у $1(9 \%)$ - HCV. Рівень антитромбіну-III в досліджуваній групі дорівнював 87,5\%, у пацієнтів із наявною супутньою патологією - 110,4\%, що свідчить про якісний дефіцит антитромбіну-III у пацієнтів із супутнім інфекційним захворюванням. Середні показники активованого часу згортання в досліджуваній групі пацієнтів становили $352,4 \pm 18,6$ с, після додаткового введення синтетичного антитромбіну-III в умовах штучного кровообігу вони досягали $535 \pm 77 \mathrm{c}$.
\end{abstract}

Ми рекомендуємо емпіричне використання синтетичного антитромбіну-III кардіохірургічним хворим при АСТ (activated coagulation time) менше 400 с для виключення інтраопераційних ускладнень у вигляді тромбозів.

Ключові слова: антитромбін-ІІІ, штучний кровообіг, гепарин, активований час згортання.

Патологія серцево-судинної системи є однією 3 основних причин захворюваності та смертності в багатьох економічно розвинених країнах світу. Потенційний успіх хірургічного лікування серцевої патології залежить від адекватної корекції вади, відновлення перфузії міокарда та профілактики післяопераційних ускладнень [1]. В наші дні основна кількість операцій на серці проводиться в умовах штучного кровообігу (ШК), що супроводжується порушенням гемостазу [7].

Одним з етапів підготовки до ШК є гепаринізація [6]. Дозування гепарину для проведення антикоагуляції перед ШК складає 300 ОД/кг, однак для деяких пацієнтів цієї дози може бути недостатньо, у зв'язку із цим адекватність антикоагуляції необхідно оцінювати індивідуально на основі визначення АCT (activated coagulation time). Відомо, що АСТ більше 400 с запобігає утворенню фібрин-мономерів під час ШК. Саме тому референті значення АСТ у нашій клініці досягають 460-480 с.

Мета дослідження - визначити зв'язок між рівнем антитромбіну-III і результатом активованого часу згортання та вплив застосування синтетичного антитромбіну-III на систему гемостазу під час штучного кровообігу та в ранньому післяопераційному періоді.

Матеріали та методи дослідження. На базі ДУ «НПМЦДКК» (клініка для дорослих) протягом 2016 року було проведено 661 хірургічне втручання із застосуванням ШК. В основу публікації покладено спосте- реження за $11(1,66 \%)$ пацієнтами з рівнем АСТ менше 400 с. Хірургічне лікування, анестезіологічно-перфузіологічне забезпечення та реанімаційне ведення цих пацієнтів проводилося за методикою, прийнятою в установі.

Протягом 2016 року в нашій клініці були виявлені ускладнення у двох пацієнтів у вигляді постперфузійних тромбозів: великий тромб у стовбурі та лівій гілці легеневої артерії, що зумовлювалося вихідним низьким рівнем антитромбіну-III, тромбоз дистальних відділів гомілкових артерій правої стопи.

В результаті аналізу цих випадків було вирішено визначати рівень антитромбіну-ІІІ у тих пацієнтів, у яких не досягається бажаний АСТ.

Антитромбін-III належить до серинових протеаз, синтезується гепатоцитами і ендотелієм судин. У кровотоці з'єднується з гепарином, і саме комплекс антитромбін-III - гепарин є головним інгібітором тромбіну та цілої низки інших факторів згортання крові (VIIa, IXа, Ха, XIa, XIIa), калікреїну та плазмину [4]. Даний комплекс становить до $80 \%$ усієї протизгортальної системи організму. Самостійна дія антитромбінуIII $є$ відносно неефективною, але в комбінації з гепарином швидкість реакції інгібірування факторів згортання значно прискорюється. Дефіцит антитромбіну-III $(0,02-1 \%$ серед населення) може бути вродженим або набутим. Головним клінічним проявом недостатності антитромбіну-III є тромбози [5]. Це може бути зумов- 
лено як зменшеною кількістю, так і структурними змінами антитромбіну-III.

Виділяють два основні типи дефіциту антитромбіну-ІІІ:

- тип I (кількісний) - характеризується недостатньою кількістю антитромбіну III;

- тип II (якісний) - характеризується нормальною кількістю антитромбіну III, який не в змозі здійснити функцію інгібітору коагуляції [5].

Відтак у випадках виявлення нормального рівня антитромбіну-III необхідно у пацієнта виключати якісні зміни даного антикоагулянту.

Протягом 2016 року на базі ДУ «НПМЦДКК» було проаналізовано дані пацієнтів, у яких рівень АСТ інтраопераційно був менше 400 с. Результати визначення рівня антитромбіну-ІІІ в досліджуваній групі, яку складали 11 пацієнтів (4 - жіночої статі, 7 - чоловічої), наведено в табл. 1.

Як видно з табл. 1, у цих пацієнтів не тільки кількісна недостатність антитромбіну-III. У пацієнтів із нормальним рівнем антитромбіну-III в анамнезі інфекційний ендокардит, що свідчить про вплив захворювання на якість специфічного білка. Залежності порушень у згортальній системі від віку або ваги пацієнтів не виявлено.

У середньому АСТ до підключення до ШК у досліджуваних пацієнтів складав $352.4 \pm 18,6$ с, спроби додаткового введення гепарину (10 000 ОД) не дали бажаних результатів. Саме тому було прийнято рішення емпіричного введення синтетичного антитромбіну-ІІІ (препарат «Атенатив») для лікування передбачуваної недостатності антитромбіну-III. Наступний контроль рівня АСТ через 10-20 хвилин показав середній результат $535 \pm 77 \mathrm{c}$, що є безпечним для проведення кардіохірургічного втручання в умовах штучного кро-

\section{Таблиця 1}

Рівень антитромбіну-ІІІ у досліджуваній групі пацієнтів

\begin{tabular}{|c|c|c|c|c|}
\hline & Вік & Вага & $\begin{array}{l}\text { Рівень антит- } \\
\text { ромбіну-ІІІ }\end{array}$ & $\begin{array}{l}\text { Супутнє захво- } \\
\text { рювання }\end{array}$ \\
\hline 1. Пацієнт Н. & 56 & 74 & $163 \%$ & $\begin{array}{l}\text { Інфекційний } \\
\text { ендокардит }\end{array}$ \\
\hline 2. Пацієнт Мк. & 23 & 46 & $78 \%$ & \\
\hline 3. Пацієнт Мш. & 39 & 87 & $82 \%$ & \\
\hline 4. Пацієнт Р. & 28 & 68 & $98 \%$ & $\begin{array}{l}\text { Інфекційний } \\
\text { ендокардит }\end{array}$ \\
\hline 5. Пацієнт Мх. & 55 & 92 & $51 \%$ & \\
\hline 6. Пацієнт Б. & 68 & 60 & $57 \%$ & \\
\hline 7. Пацієнт Дз. & 49 & 70 & $77 \%$ & \\
\hline 8. Пацієнт Т. & 56 & 91 & $65 \%$ & \\
\hline 9. Пацієнт К. & 69 & 70 & $93 \%$ & $\mathrm{HCV}$ \\
\hline 10. Пацієнт С. & 63 & 81 & $101 \%$ & $\begin{array}{l}\text { Інфекційний } \\
\text { ендокардит }\end{array}$ \\
\hline 11. Пацієнт Д. & 46 & 102 & $97 \%$ & $\begin{array}{l}\text { Інфекційний } \\
\text { ендокардит }\end{array}$ \\
\hline
\end{tabular}

вообігу. Ускладнень у ранньому післяопераційному періоді у даних пацієнтів не було.

Обговорення. Giancarlo Liumbruno, Francesco Bennardello, Angela Lattanzio, Pierluigi Piccoli, Gina Rossetti (as Italian Society of Transfusion Medicine and Immunohaematology (SIMTI) Working Party) у своїx peкомендаціях стосовно використання антитромбінових концентратів і концентратів протромбінового комплексу вказують, що концентрати можуть бути терапевтично корисні у випадках первинного та набутого дефіциту; вони мають використовуватися в клінічних умовах, у пацієнтів низьким рівнем функціонального АТ, що приводить до тромботичного дисбалансу в гемостазі [11].

Mikkel Allingstrup, Jшrn Wetterslev, Frederikke B. Ravn, Ann Merete Mшller, Arash Afshari провели систематичний огляд з мета-аналізу і пробного послідовного аналізу використання антитромбіну-III і дійшли висновку, що існує недостатньо доказів для підтримки АT-III заміщення в будь-якої категорії критично хворих учасників, у тому числі із сепсисом і ДВСсиндромом. AT-III не впливає на показник летальності, але підвищує ризик кровотечі.

У той час у рандомізованому мультицентровому дослідженні Gando S., Saitoh D., Ishikura H. et al. антитромбін не впливав на показники недостатності органів і систем. Препарат сприяв збільшенню кількості тромбоцитів, проте не впливав на показники ферментативного гемостазу та фібринолізу. Автори доходять висновку, що у пацієнтів із ДВС-синдромом на тлі сепсису антитромбін у помірних дозах покращує сумарну бальну оцінку синдрому без збільшення ризику кровотечі.

Висновки. Проведено аналіз групи пацієнтів із нормальним рівнем антитрмбіну-III, але недостатнім рівнем АСТ, виявили, що вірогідною причиною якісної недостатності антитромбіну-III є супутнє інфекційне захворювання. Рекомендуємо емпіричне використання синтетичного антитромбіну-III кардіохірургічним хворим при АСТ менше 400 с для виключення інтраопераційних ускладнень, пов'язаних із дисфункцією ендотелію, внаслідок контакту крові з екстракорпоральною поверхнею, що ініціює розвиток «системної запальної реакції», яка характеризується активацією коагуляції, фібринолізу та запалення.

\section{Література}

1. Antithrombin III for critically ill patients: a systematic review with meta-analysis and trial sequential analysis / Allingstrup Mikkel, Wetterslev Jwrn, Ravn Frederikke B. et al. // Intensive Care Medicine. - 9 February 2016. Vol. 42 (4). - P. 505-520.

2. Bical O. M. Comparison of the inflammatory response between miniaturized and standard $\mathrm{CPB}$ circuits in aortic valve surgery / O. M. Bical, Y. Fromes, D. Gaillard et al. // Eur. J. Cardiothorac. Surg. - 2006. - Vol. 29, № 5. - P. 699-702.

3. Burkhart C. S. Modifiable and nonmodifiable risk factors for postoperative delirium after cardiac surgery with 
cardiopulmonary bypass / C. S. Burkhart, S. Dell-Kuster, M. Gamberini et al. // J. Thorac. Cardiovasc. Surg. 2010. - Vol. 24. - P. 555-559.

4. Antithrombin concentrate use in children receiving unfractionated heparin for acute thrombosis / Diaz R., Moffett B. S., Karabinas S. et al. // J Pediatr. - 2015. Vol. 167. - P. 645-649.

5. Finley Alan, Greenberg Charles. Review article: heparin sensitivity and resistance: management during cardiopulmonary bypass // Anesthesia and analgesia. 2013-06-01. - Vol. 6. - P. 1210-1222.

6. A randomized, controlled, multicenter trial of the effects of antithrombin on disseminated intravascular coagulation in patients with sepsis / Gando S., Saitoh D., Ishikura H. et al. // Critical Care. - 2013. - Vol. 1. - R297.
7. Guidelines for antithrombin use at ucdmc. 6/2015.

8. Edward F. Goljan (2011). Pathology. Mosby/Elsevier. Retrieved 24 August 2014. - P. 251.

9. Peripheral nerve injuries during cardiac surgery: risk factors, diagnosis, prognosis, and prevention / Sharma A. D., Parmley C. L., Sreeram G. et al. // J Thorac Cardiovasc Surg. - 1991. - Vol. 102. - P.724-9.

10. Knapik P., Cieśla D. Incidence and prediction of permanent neurological deficits after cardiac surgery - are the existing models of prediction truly global? // Eur J Cardiothorac Surg. - 2010. - Vol. 37. - P. 717-723.

11. Recommendations for the use of antithrombin concentrates and prothrombin complex concentrates // Blood Transfus. - 2009 Oct. - Vol. 7 (4). - P. 325-334.

\title{
The first experience of using synthetic Antithrombin-III (Athenativ) in cardiosurgical practice
}

\author{
Dehtiar V., Zhovnir V., Boichenko O., Chanhli N. \\ Ukrainian Children's Cardiac Center (Kyiv)
}

Nowadays, the main share of heart surgery performed under artificial circulation, accompanied by a violation of hemostasis. Deficit antithrombin III is $0.02-1 \%$ of the population. The main clinical manifestation of deficiency of antithrombin III is thrombosis. The work conducted its own study of communication between levels of antithrombin-III and the result of the activated clotting time during cardiopulmonary bypass in cardiac practice.

Demonostrated that the quantitative and/or qualitative deficiency of antithrombin-III results in early postoperative complications and disorders in the hemostatic system.

During 2016 at the GI «Scientific-Practical Children`s Cardiac Center» an analysis of 11 patients, average age amounted to $50,2 \pm 27,2$ years. In $5(45.4 \%)$ patients were available concomitant diseases, in $4(36.4 \%)$ patients - infective endocarditis, in $1(9 \%)-\mathrm{HCV}$. The level of antithrombin-III in the study group amounted to $87.5 \%$ in patients with existing co-morbidities $-110.4 \%$, indicating a qualitative deficiency of antithrombin-III in patients with concomitant infectious disease. Averages activated coaghulation time in patients formed the study group $352,4 \pm 18,6$ seconds after the introduction of additional synthetic antithrombin-III under artificial circulation it reached $535 \pm 77 \mathrm{~s}$.

We recommend using empirical synthetic antithrombin-III cardiac patients with ACT less than 400 seconds for the exclusion of intraoperative complications such as thrombosis.

Key words: antithrombin-III, cardiopulmonary bypass, heparin, activated coagulation time.

\section{Первый опыт использования синтетического антитромбина-III (Атенатив) в кардиохирургической практике}

\author{
Дегтярь В. В., Бойченко Е. Н., Жовнир В. А., Чангли Н. А. \\ ГУ «Научно-практический медицинский центр детской кардиологии и кардиохирургия МЗ Украины» (Киев)
}

В наши дни основное количество операций на сердце проводится в условиях искусственного кровообращения, сопровождающегося нарушением гемостаза. Дефицит антитромбина-III составляет 0,02-1\% среди населения. Главным клиническим проявлением недостаточности антитромбина-ІІІ являются тромбозы. В работе проведено собственное исследование связи между уровнем антитромбина-ІІІ и результатом активированного времени свертывания в течение искусственного кровообращения в кардиохирургической практике. Показано, что количественная и/или качественная недостаточность антитромбина-ІІІ приводит к ранним послеоперационным осложнениям и нарушениям в системе гемостаза.

В течение 2016 г. на базе ГУ «Научно-практический медицинский центр детской кардиологии и кардиохирургии» был проведен анализ данных 11 пациентов, средний возраст которых составлял 50,2士27,2 года. У 5 (45,4\%) пациентов имелось сопутствующее заболевание: у 4 (36,4\%) - инфекционный эндокардит, у 1 (9\%) - HCV. Уровень антитромбина-III в исследуемой группе был равен 87,5\%; у пациентов с имеющейся сопутствующей патологией $-110,4 \%$.Это свидетельствует о качественном дефиците антитромбина-III у пациентов с сопутствующим инфекционным заболеванием. Средние показатели активированного времени свертывания в исследуемой группе пациентов составляли $352,4 \pm 18,6$ с, после дополнительного введения синтетического антитромбина-III в условиях искусственного кровообращения он достигал $535 \pm 77$ с.

Мы рекомендуем эмпирическое использование синтетического антитромбина-III кардиохирургическим больным при АСТ меньше 400 с в целях исключения интраоперационных осложнений в виде тромбозов.

Ключевые слова: антитромбин-ІІІ, искусственное кровообращение, гепарин, активированное время свертываемости. 